\title{
The Relationship between Alu I Polymorphisms in the Calcitonin Receptor Gene and Fluorosis Endemic to Chongqing, China
}

\author{
Miao Jiang ${ }^{\mathrm{a}}$ Lihong Mu $\mathrm{M}^{\mathrm{a}}$ Yingxiong Wang ${ }^{\mathrm{b}}$ Wei Yan ${ }^{\mathrm{c}}$ Yongzhuo Jiao ${ }^{\mathrm{a}}$ \\ a Department of Epidemiology, Faculty of Public Health and Management and b Faculty of Basic Medical Sciences, \\ Chongqing Medical University, and ${ }^{C}$ Institution of Endemic Disease Prevention, Center for Disease Control and \\ Prevention in Chongqing, Chongqing, PR China
}

\section{Key Words}

Endemic fluorosis - Calcitonin receptor gene .

Alu I polymorphism . Fluoride

\begin{abstract}
Objective: This study explored the association between an Alu I polymorphism at position 1,377 of the calcitonin receptor (CTR) gene and endemic fluorosis. Subjects and Methods: A case-control study of 321 participants was conducted in regions with high fluorosis rates (Wushan and Fengjie counties) and those without high fluorosis rates (Yubei Qu county; termed nonfluorosis areas) in Chongqing, China. The participants were divided into three groups: the fluorosis group (FG) from areas with high fluoride exposure (121), the nonfluorosis group (NFG) from areas with high fluoride exposure (130), and a control group (CG) from areas with no excessive fluoride exposure (70). An Alu I polymorphism in the CTR gene was genotyped using polymerase chain reaction-restriction fragment length polymorphism analysis. $\boldsymbol{R e}$ sults: The genotype distributions within each group were as follows: CC $60.33 \%(73 / 121)$, CT $30.58 \%(37 / 121)$ and TT $9.09 \%(11 / 121)$ for the FG; CC $74.62 \%(97 / 130)$, CT $21.54 \%$ (28/130) and TT 3.85\% (5/130) for the NFG, and CC 68.57\% (48/70), CT $31.43 \%$ (22/70) and TT 0\% (0/70) for the CG. Significant differences in Alu I genotypes were observed among
\end{abstract}

the groups $\left(x^{2}=12.317, u=4, p=0.015\right)$. Allele frequencies of CTR genotypes differed significantly among the groups $\left(\mathrm{X}^{2}=8.859, \mathrm{v}=2, \mathrm{p}=0.012\right): \mathrm{C} 75.62 \%(183 / 242)$ and $\mathrm{T} 24.38 \%$ (59/242) for the FG, C $85.38 \%(222 / 260)$ and T $14.62 \%(38 / 260)$ for the NFG, and C 84.29\% (118/140) and T 15.71\% (22/140) for the CG. Conclusion: An association between fluorosis and the Alu I polymorphism in the CTR gene was observed in fluoride-exposed populations.

(c) 2014 S. Karger AG, Basel

\section{Introduction}

Fluorosis is a chronic disease caused by regular consumption of an amount of fluoride exceeding the safety threshold, resulting in major health problems in humans. Fluorosis is prevalent in many countries around the world [1], and a significant positive relationship between fluoride intake in drinking water (Chinese national standard of $1.2 \mathrm{mg} / \mathrm{l}[2])$ and the prevalence of fluorosis has been demonstrated [3]. Excessive fluoride intake can cause damage predominantly in teeth and bones, resulting in dental fluorosis and skeletal fluorosis, respectively [4]. In recent years, the incidence of fluorosis in endemic fluorosis areas in China has tended to decline; currently, about 43 million people have dental fluorosis and 3 million have

\begin{tabular}{ll}
\hline KARGER 125/\% & $\begin{array}{l}\text { @ 2014 S. Karger AG, Basel } \\
\text { 1011-7571/14/0241-0080\$39.50/0 Openger }\end{array}$ \\
$\begin{array}{l}\text { E-Mail karger@karger.com } \\
\text { www.karger.com/mpp }\end{array}$ & $\begin{array}{l}\text { This is an Open Access article licensed under the terms of the } \\
\text { Creative Commons Attribution-NonCommercial 3.0 Un- } \\
\text { ported license (CC BY-NC) (www.karger.com/OA-license), } \\
\text { applicable to the online version of the article only. Distribu- } \\
\text { tion permitted for non-commercial purposes only. }\end{array}$
\end{tabular}


skeletal fluorosis in China [4]. Fluorosis is still a major public health problem and an increasing disease burden for many countries. In Chongqing, a typical coal-burning region of China with a high incidence of endemic fluorosis, data from 2002 to 2004 showed that the prevalence of dental fluorosis was $45.86 \%$, with moderate and severe fluorosis observed in individuals living in the remote mountainous areas (e.g. the prevalence of dental fluorosis in Pengshui has been reported to be as high as 80\% [5]).

However, no studies have assessed the relationship between calcitonin receptor (CTR) gene polymorphisms and fluorosis. Therefore, in this manuscript, we present a case-control study conducted in the Chongqing region to investigate the association between CTR gene (Alu I) polymorphisms and dental fluorosis.

\section{Materials and Methods}

This study was approved by the Medical Research Ethics Committees, Faculty of Medicine, Chongqing Medical University. Informed consent for all subjects was obtained from participants or their parents or legal guardians.

\section{Location and Subjects}

The case group consisted of 100 children (8-12 years of age) with a confirmed diagnosis of dental fluorosis and 21 adult patients randomly selected from Wushan county with skeletal fluorosis, confirmed by clinical criteria and standard X-ray diagnosis $[6,7]$. The children were selected using a stratified random method: 5 boys and 5 girls were selected randomly from each age group. Dental fluorosis was assessed in all permanent teeth using Dean's fluorosis index. The internal control group consisted of 8- to 12-yearold children without dental fluorosis. The children in the case and internal control groups were matched by age, gender and living conditions (according to region), with 1:1 pairwise matching. The external control group from nonepidemic areas was matched to members of the case group ('patients') by age and gender. One hundred patients ( 13 with very mild fluorosis and 87 with mild fluorosis, defined by Dean's fluorosis index), 100 internal control subjects and 50 external control subjects comprised the research set. All the children were diagnosed by two experienced dentists and two epidemiologists. Thirty internal control subjects (aged $43.0 \pm 14.2$ years) were matched with patients by age ( \pm 3 years), gender and living conditions, and 20 external control subjects (aged $42.0 \pm 15.3$ years) were matched with patients by age ( \pm 3 years) and gender. All subjects were diagnosed by one orthopedic surgeon, one radiologist and two epidemiologists. The study was conducted in regions with a high incidence of fluorosis (Wushan and Fengjie counties) and regions without a high incidence of fluorosis (Yubei Qu county) in Chongqing, China. In addition to the groups detailed above, the subjects $(\mathrm{n}=321)$ were also divided into three further groups: the fluorosis group (FG) from areas with high fluoride exposure; the nonfluorosis group (NFG) from areas with high fluoride exposure, and the control group (CG) from areas with no excessive fluoride exposure.

CTR Gene Alu I Polymorphism in Fluorosis
Table 1. Number of patients with specific CTR genotypes in each group and adherence to the Hardy-Weinberg equilibrium

\begin{tabular}{lrrrrrl}
\hline Group & $\mathrm{n}$ & \multicolumn{3}{c}{ CTR genotype } & \multirow{2}{*}{$\chi^{2}$} & $\mathrm{p}$ \\
\cline { 3 - 5 } & & $\mathrm{CC}$ & $\mathrm{CT}$ & $\mathrm{TT}$ & & \\
\hline FG & 121 & 73 & 37 & 11 & 3.526 & 0.060 \\
NFG & 130 & 97 & 28 & 5 & 2.441 & 0.118 \\
CG & 70 & 48 & 22 & 0 & 2.433 & 0.119 \\
\hline Total & 321 & 218 & 87 & 16 & 3.376 & 0.066 \\
\hline
\end{tabular}

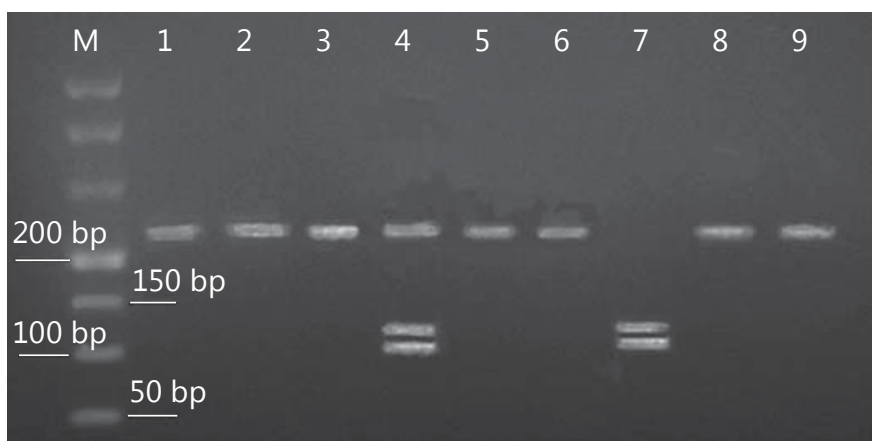

Fig. 1. PCR analysis yielded only a 228-bp band for the CC genotype (wild genotype), two fragments of 120 and $108 \mathrm{bp}$ for the TT genotype (homozygote genotype), and 228, 120 and $108 \mathrm{bp}$ for the CT genotype (heterozygote genotype). CC genotype: 1, 2, 3, 5, 6, 8, 9; TT genotype: 7; CT genotype: 4 . M = DL500 marker.

\section{DNA Extraction}

Blood samples $(5 \mathrm{ml})$ of all the participants were collected from the brachial vein, immediately transferred into EDTA-coated tubes and stored at $-20^{\circ} \mathrm{C}$. Genomic DNA was extracted from the blood samples of all participants with a DNA extraction kit (centrifugal column type; BioTeke Corp., Beijing, China).

\section{Polymerase Chain Reaction}

Polymerase chain reaction (PCR) analysis of the 1377C/T CTR gene polymorphism was carried out in a total volume of $50 \mu \mathrm{l}$, containing $25 \mu \mathrm{l}$ of Premix Taq, $1 \mu \mathrm{l}$ of each primer $(10 \mu \mathrm{mol} / \mathrm{l}), 5 \mu \mathrm{l}$ of genomic DNA, and sterilized $\mathrm{ddH}_{2} \mathrm{O}$ to the final volume. Primers for the CTR gene polymorphism have been described previously [8], and the length of the amplicon was $228 \mathrm{bp}$. Mixing, instantaneous centrifugation and PCR amplification were performed using a programmable thermal cycler. The cycling conditions were as follows: $94^{\circ} \mathrm{C}$ for $5 \mathrm{~min}, 35$ cycles at $94^{\circ} \mathrm{C}$ for $1 \mathrm{~min}, 57^{\circ} \mathrm{C}$ for $30 \mathrm{~s}, 72^{\circ} \mathrm{C}$ for $30 \mathrm{~s}$, and a final extension at $72^{\circ} \mathrm{C}$ for $10 \mathrm{~min}$. The PCR products were subjected to gel electrophoresis $(110 \mathrm{~V}, 72 \mathrm{~mA}$, $40 \mathrm{~min}$ ) to check for the presence of a 228-bp band. Products were purified using the ethanol/sodium acetate method and digested overnight with $\mathrm{Alu} \mathrm{I}$ at $37^{\circ} \mathrm{C}$, according to a previously published protocol [8]. Reaction mixtures had a final volume of $20 \mu \mathrm{l}$, containing $2 \mu \mathrm{l}$ of $10 \times \mathrm{NEB}$ buffer, $10 \mu \mathrm{l}$ of amplification product, 0.5 $\mu \mathrm{l}$ of the restriction enzyme $A l u \mathrm{I}$, and $7.5 \mu \mathrm{l}$ of sterilized $\mathrm{ddH}_{2} \mathrm{O}$. 
Table 2. Distribution of CTR genotypes and allelic frequencies in the different groups $(\alpha=0.05)$

\begin{tabular}{|c|c|c|c|c|c|c|c|}
\hline & $\begin{array}{l}\text { FG } \\
(\mathrm{n}=121)\end{array}$ & $\begin{array}{l}\text { NFG } \\
(\mathrm{n}=130)\end{array}$ & $\begin{array}{l}\text { CG } \\
(\mathrm{n}=70)\end{array}$ & $\begin{array}{l}\text { Total } \\
(\mathrm{n}=321)\end{array}$ & OR $[95 \% \mathrm{CI}]$ & $x^{2}$ & $\mathrm{p}$ \\
\hline \multicolumn{8}{|c|}{ Genotype } \\
\hline $\mathrm{CT}$ & $37(30.58)$ & $28(21.54)$ & $22(31.43)$ & $87(27.10)$ & $1.605[0.908-2.836]^{\mathrm{a}}, 0.961[0.509-1.815]^{\mathrm{b}}$ & $2.669^{\mathrm{a}}, 0.015^{\mathrm{b}}$ & $0.114^{\mathrm{a}}, 1.000^{\mathrm{b}}$ \\
\hline TT & $11(9.09)$ & $5(3.85)$ & 0 & $16(4.89)$ & $2.5[0.842-7.419]^{\mathrm{a}},-$ & $2.888^{\mathrm{a}}, 6.573^{\mathrm{b}}$ & $0.121^{\mathrm{a}}, 0.008^{\mathrm{b}}$ \\
\hline \multicolumn{8}{|c|}{ Allele } \\
\hline
\end{tabular}

Table 3. Distribution of CTR genotypes and allelic frequencies in the different groups $(\alpha=0.01)$

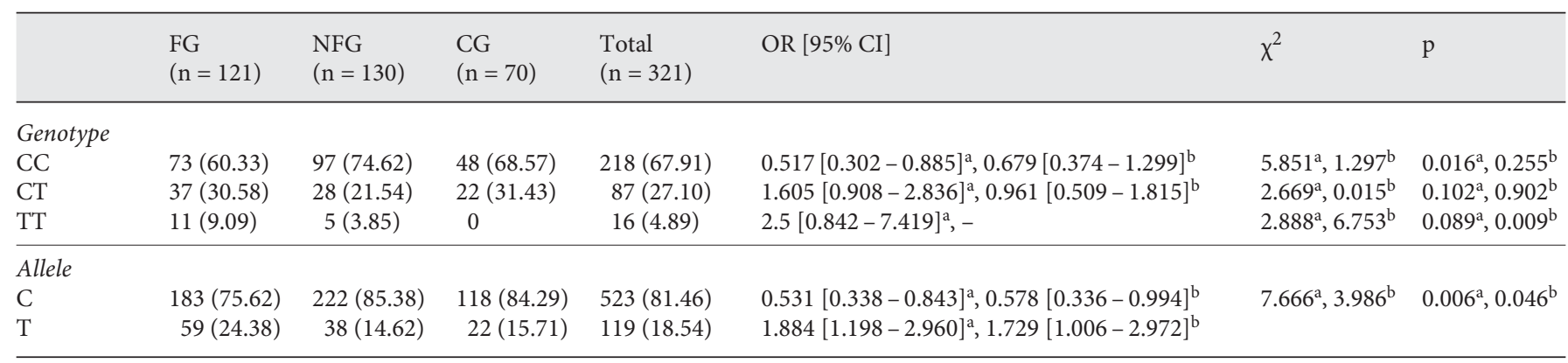

Data are presented as $n$ with percentage in parentheses. ${ }^{\text {a }}$ FG versus NFG. ${ }^{b}$ FG versus CG.

Data Analysis

All statistical analyses were performed using SPSS version 17.0. The gene-counting method was used to estimate allele frequencies. Deviation in genotype distribution from the expected HardyWeinberg equilibrium was estimated by the $\chi^{2}$ test $(\alpha=0.05)$. The significance of differences in allele frequencies between groups was also estimated by the $\chi^{2}$ independence test $(\alpha=0.01)$.

\section{Results}

The PCR analysis yielded only a 228-bp band for the CC genotype, two fragments of 120 and 108 bp for the TT genotype, and 228, 120 and $108 \mathrm{bp}$ for the CT genotype (fig. 1). The distribution of genotypes for the Alu I restriction fragment length polymorphism (RFLP) did not deviate from the Hardy-Weinberg equilibrium (table 1; p > 0.05). The genotype and allele frequencies of the Alu I RFLP in the CTR gene are shown in table $2(\alpha=0.05)$. The observed genotype frequencies of CC, CT and TT were $67.91,27.1$ and $4.98 \%$, respectively, and the frequencies of the $\mathrm{C}$ and $\mathrm{T}$ alleles were 81 and 19\%, respectively. There were statistically significant differences among the three groups with respect to both genotype distribution $\left(\chi^{2}=\right.$ 12.317, $\mathrm{p}=0.015)$ and allele frequency $\left(\chi^{2}=8.859, \mathrm{p}=\right.$ 0.012 ). Moreover, statistically significant differences were observed between the case and control groups with respect to genotype distribution (FG vs. NFG: $\chi^{2}=6.57$, $\mathrm{p}=0.037$; FG vs. CG: $\chi^{2}=6.849, \mathrm{p}=0.033$; NFG vs. CG: $\left.\chi^{2}=4.702, p=0.095\right)$ and allele frequency (FG vs. NFG: $\chi^{2}=7.666, p=0.006, \mathrm{OR}=0.531,95 \%$ CI $0.338-0.834 ; \mathrm{FG}$ vs. CG: $\chi^{2}=3.986, p=0.046$, OR $=0.578,95 \%$ CI $0.336-$ 0.994; NFG vs. CG: $\chi^{2}=0.086, p=0.769, \mathrm{OR}=1.089,95 \%$ CI 0.616-1.927).

The genotype and allele frequencies of the Alu I RFLP in the CTR gene are shown in table $3(\alpha=0.01)$. The results are similar to data obtained for $\alpha=0.05$. The two groups (NFG and CG) exhibited the same allelic distribution $\left(\chi^{2}=0.086, p=0.769\right.$, OR $=1.089,95 \%$ CI $0.616-$ 1.927). Statistically significant differences were observed between the FG and NFG or CG groups with respect to allele frequency distribution $\left(\chi^{2}=8.786, \mathrm{p}=0.003, \mathrm{OR}=\right.$ $0.547,95 \%$ CI $0.366-0.818)$. 


\section{Discussion}

The distribution sequence of the mixed CTR genotype - CC followed by CT and TT - of this study in Chinese subjects is consistent with the CTR genotype frequency distribution in Asians $[9,13]$, but different from that in Caucasians $[9,10]$. Additionally, the allele frequencies, i.e. the presence of the $\mathrm{C}$ allele in $81.46 \%$ and the $\mathrm{T}$ allele in $18.54 \%$ of individuals, are similar to those reported for Guangzhou [11], Shanghai [12] and Beijing [13], but are clearly different from the frequencies observed in Italian populations (for which the $\mathrm{T}$ allele was the most frequent in 49.7\%) [14,15]. Thus, the present data support the observation that the distribution of CTR genotypes differs between Chinese and Caucasians.

Considering the distribution of genotypes in the FG, NFG and CG groups, the TT genotype was more frequent in the FG than in the NFG group ( 9.09 vs. $3.85 \%$, respectively), probably because fluorosis may be influenced by the TT polymorphism of the CTR genotype. Furthermore, the CTR allele frequency distribution of the case and control groups was different. A possible explanation could be that carrying the $\mathrm{C}$ allele reduced the risk of fluorosis and, hence, this allele may have a protective effect against fluorosis. Thus, our data indicated that the $\mathrm{T}$ allele of the Alu I gene polymorphism is associated with an increased risk of fluorosis. Gene-gene or gene-environment interactions could lead to the varying genetic effects ob- served in different populations. Our results further confirmed that there were significant differences in the distribution of alleles among fluorosis patients and control subjects.

\section{Conclusion}

Our data supported the hypothesis that the Alu I polymorphism of the CTR gene may be one of the genetic components associated with fluorosis. Due to the modest sample size, it is essential to replicate these findings in different populations with larger sample sizes, and investigation of other related genes will be needed to clarify the relationship between this polymorphism and fluorosis.

\section{Acknowledgements}

This study was supported by a grant (Chongqing Geological Exploration, 2010-2012) from the Chongqing Geological Prospecting Development Authority. We thank the members of the Science and Technology Department of Chongqing Geological Prospecting Development Authority and the Scientific Research Office of Chongqing Medical University. We are also grateful for the advice provided by the CDC of Chongqing.

\section{Disclosure Statement}

The authors have no conflicts of interest to disclose.

\section{References}

1 Reddy D: Neurology of endemic skeletal fluorosis. Neurol India 2009;57:7-12.

2 Wang C, Gao YH, Wang W, et al: A national cross-sectional study on effects of fluoridesafe water supply on the prevalence of fluorosis in China. BMJ Open 2012;2:001564.

3 Wang B, Zheng B, Zhai C, et al: Relationship between fluorine in drinking water and dental health of residents in some large cities in China. Environ Int 2004;30:1067-1073.

-4 Jha SK, Mishra VK, Sharma DK, et al: Fluoride in the environment and its metabolism in humans. Rev Environ Contam Toxicol 2011; 211:121-142.

5 Xiao BZ, Liao WF, Wu CG, et al: Analysis on endemic fluorosis of burning coal pollution in Chongqing. Chin J Endemiol 2005; 24:547550.

6 Ministry of Public Health of China: Clinical Index Diagnosis Standard of Endemic Skeletal Fluorosis WS192-2008. Beijing, China Standard Press, 2008.
7 Ministry of Public Health of China: X-Ray Diagnosis Standard of Skeletal Fluorosis WS192-2008. Beijing, China Standard Press, 2008. http://www.tsinfo.js.cn/inquiry/gbtdetail.aspx?A100=WS\%20192-2008.

8 Yang Y, Wang SG, Ye ZC, et al: Single nucleotide polymorphism of calcitonin receptor gene and idiopathic hypercalciuria. Chin J Urol 2006; 10:695-698.

-9 Nakamura M, Morimoto S, Zhang Z, et al: Calcitonin receptor gene polymorphism in Japanese women: correlation with body mass and bone mineral density. Calcif Tissue Int 2001;68:211-215.

10 Charopoulos I, Trovas G, Stathopoulou M, et al: Lack of association between vitamin $\mathrm{D}$ and calcitonin receptor gene polymorphisms and forearm bone values of young Greek males. J Musculoskelet Neuronal Interact 2008;8: 196-203.

11 Li DF, Wu W, Cai XZ, et al: Association of calcitonin receptor gene polymorphism with bone mineral density in postmenopausal women in Guangzhou, South China. Prevent Med J 2005;31:14.

12 Zhao HY, Liu JM, Ning G, et al: Association of calcitonin receptor gene polymorphism with bone mineral density in Shanghai women (in Chinese). Zhongguo Yi Ke Yuan Xue Bao 2003;25:258-261.

13 Zhang ZL, Meng XW, Zhou XY, et al: Association of vitamin $\mathrm{D}$ receptor gene and calcitonin receptor gene polymorphisms with bone mineral density in women of the Han nationality in Beijing area. Chin J Endocrinol Metab 2002;18:90-94.

14 Everett ET: Fluoride's effects on the formation of teeth and bones, and the influence of genetics. J Dent Res 2011;90:552-560.

15 Masi L, Becherini L, Colli E, et al: Polymorphisms of the calcitonin receptor gene are associated with bone mineral density in postmenopausal Italian women. Biochem Biophys Res Commun 1998;248:190-195. 